
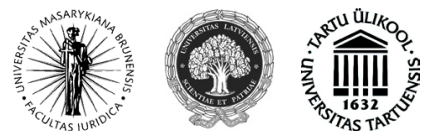

ISSN 1392-6195 (print) ISSN 2029-2058 (online) JURISPRUDENCIJA JURISPRUDENCE 2014, 21(3), p. 731-757.

\title{
VALSTYBIŲ PRIPAŽINIMO IR VALSTYBIŲ TEISIŲ PEREMMIMO SĄVEIKA
}

\author{
Birutė Kunigèlytė-Žiūkienè \\ Mykolo Romerio universiteto Teisès fakulteto \\ Tarptautinès ir Europos Sąjungos teisès institutas \\ Ateities g. 20, LT-08303 Vilnius, Lietuva \\ Telefonas (+370) 52714669 \\ Elektroninis paštas birute.kunigelyte@gmail.com
}

Pateikta 2014 m. liepos 10 d., parengta spausdinti 2014 m. rugsèjo 18 d.

doi:10.13165/JUR-14-21-3-05

\section{Ivadas}

Valstybių pripažinimo ir valstybių teisių perèmimo klausimai tarptautinèje darbotvarkèje nèra dažni, atvirkščiai - jiems iškilus tenka konstatuoti, kad ịvyko gana neeilinis ịvykis - atsirado arba bent jau pasiskelbẻ susikūrusi nauja valstybè. Tarptautinèje arenoje pasiskelbus naujam subjektui, atsiranda daugybė susijusių klausimų. Vienas pirmųjų - naujo darinio priemimo ị tarptautinę bendriją galimybè - jo pripažinimas. Kitas klausimas, su kuriuo ilgainiui greičiausiai teks susidurti, - valstybių teisių perėmimas. M. N. Shawo nuomonè, jog „pakankamai akivaizdu, kad negalima išspręsti valstybių teisių perėmimo klausimo, t. y. teisių ir ịsipareigojimų perkèlimo iš vienos valstybės kitai, pirmiausia nesusidūrus su valstybingumo problema"1, tinkamai iliustruoja minètų dviejų institutų tarpusavio santykị ir abipusę priklausomybę.

Jurisprudencija/Jurisprudence

(C) Mykolo Romerio universitetas, 2014

(C) Mykolas Romeris University, 2014
ISSN 1392-6195 (print), ISSN 2029-2058 (online) http://www.mruni.eu/lt/mokslo_darbai/jurisprudencija/ http://www.mruni.eu/en/mokslo_darbai/jurisprudencija/ 
Valstybių pripažinimo klausimai labai reikšmingi valstybių teisių perėmimui, nes tarptautinès bendrijos sprendimas ịtraukti naują valstybę i savo ratą gali nulemti, ar apskritai toks perėmimas ịvyks, o jei taip - perėmimo apimtị. Pirmiausia iškylantys klausimai - kiek valstybių pripažinimas turi įtakos valstybių teisių peremimui ir jo apimčiai, ypač priklausomai nuo valstybių susikūrimo būdo, ir kaip sprendžiama valstybių teisių perèmimo situacija tuo atveju, jei nèra visuotinio sutarimo dèl naujai susiformavusio subjekto pripažinimo, o šis yra pajègus priimti sprendimus tarptautinèje erdvèje savarankiškai.

Klausimai, susiję su valstybių pripažinimu ir teisių perėmimu šiandien ypač aktualūs: Pietų Sudanas atsiskyrẻ nuo Sudano, nepriklausomybę yra paskelbęs Kosovas, paskelbtas referendumas dèl Škotijos atsiskyrimo nuo Jungtinès Karalystės, keletas valstybių pripažino separatistinių regionų - Abchazijos ir Pietų Osetijos - nepriklausomybę, beveik visa tarptautine bendrija laikosi nepripažinimo politikos Krymo atskyrimo ir prijungimo prie Rusijos atžvilgiu ir t. t.

Valstybių pripažinimo klausimams spręsti dažnai pasitelkiama 1933 m. Montevideo konvencija dèl valstybių teisių ir pareigų ${ }^{2}$ kurioje nustatomi pagrindiniai valstybingumo kriterijai. Šiuos kriterijus pripažinimo kontekste papildè kiti regioniniai dokumentai - pavyzdžiui, Europos Bendrijos prièmé deklaraciją su gairèmis, kuriomis buvo sutarta vadovautis priimant sprendimus dèl atskirų valstybių pripažinimo ${ }^{3}$. Kadangi valstybių pripažinimas yra vienašalis pripažįstančiosios valstybès aktas (su atskiromis išimtimis galintis būti išreikštas kolektyviai), sukeliantis tiek nacionalinių, tiek tarptautinių teisinių padarinių, o valstybių, kaip ir kitų teritorinès prigimties situacijų (karo padèties, sukilimo ar neutraliteto) pripažinimui nèra taikoma specifinių kriterijų vienašalių aktų kontekste $e^{4}$, tokiems politiniams aktams gali būti taikomi Tarptautinès teisès komisijos $2006 \mathrm{~m}$. priimti Pagrindiniai principai, taikomi vienašaliams valstybių aktams, galintiems sukurti teisinius ịsipareigojimus ${ }^{5}$. Valstybių teisių perėmimo klausimams nagrinèti išleisti keli dokumentai. Pirmiausia paminètinos $1978 \mathrm{~m}$. Vienos konvencija dèl valstybių teisių perémimo sutartims (įsigaliojo 1996 m. $)^{6}$ ir $1983 \mathrm{~m}$. Vienos konvencija dèl valstybių teisių perémimo valsty-

2 Montevideo Convention on the Rights and Duties of States. League of Nations Treaty Series, vol. CLXV, 1936, No 3802, p. 20-31.

3 Declaration on the Guidelines on the Recognition of New States in Eastern Europe and in the Soviet Union (16 December 1991). European Journal of International Law [interaktyvus]. 19902004 [žiūrèta 2013-09-30]. <http://207.57.19.226/journal/Vol4/No1/art6.html\#TopOfPage>. Report of the International Law Commission Fifty-fifth session (5 May-6 June and 7 July-8 August 2003). Official Records of the General Assembly, Fifty-eight session, Supplement No. 10 (A/58/10), para 260.

5 Guiding Principles applicable to unilateral declarations of States capable of creating legal obligations, with commentaries thereto. Yearbook of the International Law Commission, 2006, vol. II, Part Two. 
bės nuosavybei, archyvams ir skoloms (kol kas neịsigaliojusi) ${ }^{7}$. Nepaisant to, kad pirmosios šalių skaičius palyginti nedidelis ${ }^{8}, o$ antroji apskritai neįsigaliojusi, šių dviejų konvencijų nuostatos gali būti naudojamos bent jau kaip gairès reglamentuojamiems klausimams spręsti. Yra ir kitų dokumentų, reguliuojančių valstybių teisių peremimo klausimus pilietybès, diplomatinės gynybos srityse ${ }^{9}$. Derètų atkreipti dèmesị, kad pagrindiniai tarptautiniai dokumentai šioje srityje - valstybių susitarimai dèl teisių peremimo klausimų.

Valstybių teisių perėmimo ir valstybių pripažinimo sąveikos klausimai nereglamentuojami jokiame viename konkrečiame dokumente. Vis dèlto pažymètina, kad, pavyzdžiui, Europos Bendrijų gairèse ${ }^{10}$ i̇sipareigojimas spręsti valstybių teisių perèmimo klausimus traktuojamas kaip vienas pripažinimo kriterijų.

Valstybių pripažinimo klausimai nagrinėjami ịvairių autorių ir gana gausiai. Pažymint, kad klausimas daugiau politinis, jis susilaukia ịvairių mokslo šakų mokslininkų susidomėjimo: teisininkų, politologų, istorikų. Iš teisès mokslo specialistų pirmiausia paminètinas $\mathrm{H}$. Lauterpachtas, valstybių pripažinimo klausimą nagrinèjęs monografijoje, kuri iki šiol laikoma vienu autoritetingiausių veikalų. Klausimą išsamiai nagrinejjo T. D. Grantas, paminètinas A. Cassese, nagrinèjantis valstybių susikūrimo ir išnykimo klausimus, taip pat C. Hillgruberis, D. Žalimas, tyręs Lietuvos nepriklausomybės atkūrimo pripažinimą, ir kiti. Valstybių teisių perėmimo klausimų nagrinèjimas taip pat susilaukia nemažai dèmesio, tačiau gana diferencijuotai pagal teisių perėmimo objektus: valstybių teisių perèmimo klausimais monografijas išleidę P. Dumberry (valstybių atsakomybės atžvilgiu), T. Chengas (komercinių ịsipareigojimų atžvilgiu), teisių peremimą sutartims nagrinẻjo A. Austas, teisių tęsimo problematiką - I. Ziemele ir kiti. Paminètini Lietuvos mokslininkai, gilinęsi ị teisių perėmimo ir / ar teisių tęsimo problematiką - L. Jakulevičiené (valstybių teisių per-

71983 Vienna Convention on Succession of States in respect of State Property, Archives and Debts, Official Records of the United Nations Conference on Succession of States in Respect of State Property, Archives and Debts. Vol. II.

$82014 \mathrm{~m}$. birželio $12 \mathrm{~d}$. duomenimis, konvencijos šalimis buvo 22 valstybès: United Nations Treaty Collection [interaktyvus]. United Nations, 2014 [žiūrèta 2014-06-12]. <https://treaties. un.org/Pages/ViewDetails.aspx?src=TREATY\&mtdsg_no=XXIII-2\&chapter=23\&lang=en $>$.

9 Valstybių teisių peremimo metu kylantiems klausimams dèl asmenų pilietybès spręsti yra priimti keli regioniniai dokumentai: 1995 m. priimta Europos Komisijos „Demokratija per teisę" (kitaip - Venecijos komisija - Europos Tarybos patariamoji institucija) deklaracija dèl valstybių teisių peremimo pasekmių fizinių asmenų pilietybei; $2006 \mathrm{~m}$. priimta ir $2009 \mathrm{~m}$. ìsigaliojusi Europos Tarybos konvencija dèl pilietybès netekimo, susijusio su valstybių teisių perėmimu, išvengimo. Jungtinių Tautų Organizacijoje parengtas straipsnių projektas dèl valstybių teisių peremimo asmenų pilietybès atžvilgiu, tačiau Generalinė Asambleja jau daugiau nei dešimtmetị negali apsispręsti, kokią formą šis dokumentas turètų igyti. Diplomatinès gynybos klausimams spręsti parengtas Diplomatinès gynybos straipsnių projektas, kurio likimas taip pat kol kas neaiškus. 
ėmimo tarptautinèms sutartims klausimais), D. Žalimas (Sovietų Sąjungos teisių tęsimo, Lietuvos Respublikos teisių tęsimo, jos pripažinimo, SSRS padarytos Lietuvai žalos atlyginimo ir kitais susijusiais klausimais). Reikia pripažinti, kad valstybių teisių perèmimo ir valstybių pripažinimo santykis nèra pakankamai ištirta tema. Mokslinius tyrimus šia tematika atliko M. Škrk, E. McWhinney ir kiti. Paminėtinas J. Klabberso ir kitų vykdytas pilotinis projektas dèl valstybių praktikos valstybių teisių peremimo ir pripažinimo klausimais, patvirtintas $1994 \mathrm{~m}$. Europos Tarybos Ad Hoc Teisès patarejų komiteto tarptautinès viešosios teisès klausimais (CAHDI), kurio pagrindu išleista to paties pavadinimo studija. Pažymètina, kad autoriai paprastai nagrinejja konkrečius valstybių pripažinimo atvejus (dažnai - Jugoslavijos išsiskyrimo kontekste), papildomai aptardami valstybių teisių peremimo klausimus arba atvirkščiai - nagrinėdami valstybių teisių perėmimo klausimus, istoriniu metodu aptaria ir pripažinimą. Tyrimų, analizuojančių šių institutų sąveikos klausimą, tarpusavio priklausomybės ryši, priklausomai nuo valstybių susikūrimo būdo, stinga.

Šiuo straipsniu siekiama išnagrinèti, kokią ịtaką valstybių pripažinimas turi valstybių teisių perėmimui, ypač priklausomai nuo valstybių susikūrimo būdo (atitinkamai - nuo teisių peremimo varianto), bei nepripažinimo politikos įtaką valstybių teisių peremimui.

Tyrimo objektas - tarptautiniai teisiniai santykiai, kylantys valstybėms pripažịstant naujai susiformavusius tarptautinès teisès subjektus ir valstybių pripažinimo ịtaka valstybių teisių perėmimo procesui priklausomai nuo valstybių susikūrimo būdo.

Tyrime taikomi dokumentų analizès, istorinis, sisteminès analizès, apibendrinimo metodai.

\section{Valstybių pripažinimas}

Valstybių pripažinimo sąvoka dažnai vartojama apibūdinti veiksmams, kuriais valstybè patvirtina, kad klausimai dèl konkrečios teisinès situacijos ar ginčo padarinio nebebus keliami ir diskutuojami ${ }^{11}$. Pripažinimas paprastai yra vienašalis valstybès aktas, tačiau pripažinimo deklaracija gali būti ịtvirtinta ir tarptautinèje sutartyje ${ }^{12}$. Valstybių pripažinimas tarptautinèje teisèje gali būti dvejopas - kai naujai susiformavusị subjektą pripažįsta atskiros valstybès (individualus pripažinimas) bei kai pripažinimas deklaruojamas tarptautinès organizacijos (kolektyvinis pripažinimas), pavyzdžiui, ES valstybės narès prièmé sprendimus ES kontekste spręsdamos klausimus, susijusius su Jugoslavijos Socialistinès Federacinès Respublikos iširimu, atskirų

11 Frowein, A. J. Recognition. Max Planc Encyclopedia of Public International Law [interaktyvus]. Heidelberg: Max Planck Institute for Comparative Public Law and International Law [interaktyvus]. Heidelberg and Oxford University Press, 2013 [žiūrèta 2013-06-25]. <http:// www.mpepil.com>.

Ibid. 
jos subjektų pripažinimu ir teisių peremimu ${ }^{13}$. Ypatingą vaidmenị valstybių pripažinimo procese turi Jungtinių Tautų Organizacija. Kai darinys priimamas ị JTO, jo valstybingumas neginčijamas - tai paaiškina ir skubą, kuria pretendentès siekia narystès: Slovėnijos, Kroatijos ir Bosnijos ir Hercegovinos skubus priemimas 1992 m. gegužę iliustruoja skubejjimą patvirtinti atsiskyrimą nuo Jugoslavijos ${ }^{14}$. Narystei JTO nereikalingas visų valstybių pripažinimas, to gyvas įrodymas yra Izraelis, kuris pripažintas 166 valstybių iš 193 JTO narių ${ }^{15}$. Tačiau, kaip minėta, naryste šioje tarptautinejje organizacijoje, kurios narèmis yra beveik visos pasaulio valstybės, suponuoja visuotinị tarptautinị pripažinimą ir atskirų valstybių nepripažinimo politika neturi jokios įtakos šalies valstybingumui. Juk „kai priimamas sprendimas priimti valstybę i Jungtines Tautas, jos valstybingumas nebegali būti kvestionuojamas, [nes] taip [būtų] ginčijamas abipusių teisių ir įsipareigojimų, kylančių iš narystès, galiojimas "16.

H. Lauterpachtas yra rašęs, kad bendruomenès pripažinimas valstybe - tai deklaravimas, kad ji atitinka valstybingumo sąlygas, keliamas tarptautinès teisès, o jei šios sąlygos tenkinamos, egzistuojančios valstybès turi pareigą tokị pripažinimą suteikti ${ }^{17}$. Pagrindiniais valstybingumo kriterijais laikomi valstybės bruožai, numatyti $1933 \mathrm{~m}$. Montevideo konvencijoje, - nuolatiniai gyventojai, apibrèžta teritorija, veiksmingas valdžios aparatas ir gebejimas užmegzti tarptautinius santykius ${ }^{18}$. Lygiai taip valstybių pripažinimui gali būti keliami papildomi reikalavimai - tokius gali numatyti, pavyzdžiui, tarptautinių organizacijų dokumentai: kaip minèta, Europos Bendrijos papildomais kriterijais pripažįstant buvusias JSFR valstybes nurodè ir susitarimo ar arbitražo būdu išspręsti valstybių teisių perèmimo klausimus, ir kitus kriterijus, tokius kaip ịsipareigojimas garantuoti etninių ir tautinių grupių bei mažumų teises, gerbti JT Chartijos nuostatas ir t. t. ${ }^{19}$

13 Europos Bendrijos buvo prièmusios gaires dèl naujų valstybių Rytų Europoje ir Sovietų Sąjungoje pripažinimo (žr. supra note 3 ) ir deklaraciją dèl Jugoslavijos, kuria išreiškiama bendroji pozicija dèl Jugoslavijos respublikų pripažinimo klausimų (žr. Declaration on Yugoslavia. Extraordinary EPC Ministerial Meeting, Brussels, 16 December 1991 [interaktyvus]. European Journal of International Law [žiūrèta 2014-02-23] <http://207.57.19.226/journal/Vol4/No1/ art7.html\#TopOfPage $>$.

14 Dugard, J.; Raič, D. The Role of Recognitionin the Law and Practice of Seccession. Secession: International Law perspectives. New York: Cambridge University Press, 2006, p. 94-137, p. 99.

15 Pavyzdžiui, Marokas ir Irakas, ratifikavę Vienos konvenciją dèl valstybių teisių perèmimo sutartims, padare pareiškimus ar išlygas, kad prisijungimas prie sutarties niekaip nereiškiąs Izraelio pripažinimo ar sutartinių santykių su Izraeliu (tiesa, Marokas, pavyzdžiui, $1994 \mathrm{~m}$. buvo užmezgęs diplomatinius santykius, o $2000 \mathrm{~m}$. juos suspendavo). Izraelio užsienio reikalų ministerija [interaktyvus]. 2013 [žiūrèta 2013-11-24]. <http://mfa.gov.il/MFA/ AboutTheMinistry/Pages/Israel-s\%20Diplomatic\%20Missions\%20Abroad.aspx\#note>.

16 Hillgruber, C. The Admission of New States to the International Community. European Journal of International Law. 1998, 9: 491-509, p. 492.

17 Lauterpacht, H. Recognition of States in International Law, 53 YALE L. J. 385, 1944.

18 Supra note 2.

19 Supra note 3. 
Derètų pažymėti, kad valstybių pripažinimas tampa svarbesnis, kai nėra aiškumo, ar naujas darinys atitinka objektyvius keliamus kriterijus; tokiu atveju pripažinimas konstatuoja tokių keliamų reikalavimų atitikimą ${ }^{20}$. Vis dèlto, kad ir kaip norètųsi tikèti H. Lauterpachtu, tarptautinèje teiseje, juolab - tarptautinèje politikoje - nèra pareigos pripažinti naujai susikūrusị subjektą. Kaip kadaise paminèjo J. L. Brierly, kalbèdamas apie vyriausybių pripažinimą, „tokio klausimo reguliavimas tarptautinėmis konvencijomis nei realizuojamas, nei pageidautinas. <...> Taikant analogiją, tai būtų lyg valstybė išleistų įstatymą, nurodantị savo piliečiams, kokius draugus pasirinkti “21 . Vis dèlto pripažinimas - iš principo politinès prigimties vienašalis valstybės aktas - sukuria teisinių padarinių ir kartu yra bent iš dalies suponuotas tarptautinès teisès normų.

Kaip pastebi J. Dugardas ir D. Raičas, dabar tarptautinèje teisèje „jau nebekyla klausimas, kada valstybės gali pripažinti atsiskyrusius darinius, siekiant išvengti išankstinio pripažinimo, bet ar jos gali apskritai tai padaryti“22. Pastarasis klausimas keliamas, siekiant nurodyti, kad neturètų būti pripažistami subjektai, susikūrę jus cogens normų pažeidimo būdu - ex injuria jus non oritur. Kai naujas darinys susikuria tarptautinès teisès pažeidimo būdu, valstybès linkusios laikytis nepripažinimo politikos, kurios kontekste labai svarbus ir tarptautinių organizacijų vaidmuo. Keletą kartų JT Saugumo Taryba, paprastai remdamasi Generalinès Asamblejos rezoliucijomis, kvietė nepripažinti atitinkamų darinių valstybėmis, pavyzdžiui, Rodezijos, paskelbusios nepriklausomybę 1965 m., Šiaurès Kipro, kaip atskiros valstybès, paskelbusios nepriklausomybę 1983 m. ${ }^{23}$, Generalinès Asamblejos $2014 \mathrm{~m}$. kovo 27 d. rezoliucija kvietė nepripažinti jokio Krymo Autonominès Respublikos ir Sevastopolio miesto statuso pasikeitimo ir susilaikyti nuo bet kokio veiksmo ar susitarimo, kuris galètu

20 Shaw, M. N. State Succession Revisited. Finnish Y.B. Int'l L. 1994, 5 (34): 34-98.

21 Tautų Sąungos Ekspertų komitetas progresyviai tarptautinès teisès kodifikacijai pirmosios sesijos aštuntojo susitikimo metu (1925 m., Ženevoje) nutaré išbraukti iš darbotvarkès punktą „Vyriausybių pripažinimo forma: tarptautinè vyriausybių, kurios nebuvo formaliai pripažintos, padètis“, pasiūlytą dr. J. L. Suarezo (Argentina). Kalbẻdamas apie vyriausybių pripažinimą, jis išreiškè savo nuomonę, kad turinti būti tarptautinè praktika ar formulè, kuri leistų automatinị vyriausybès pipažinimą tuomet, kai suverenioje valstybejje egzistuoja tokia vyriausybè (be reikšmingo atidèliojimo). Išsamiau - Future work in the field of the codification and progressive development of International Law - Working paper prepared by the Secretariat A/CN.4/145 [interaktyvus]. International Law Commission [žiūrèta 2013-11-07]. <http:// legal.un.org/ilc/documentation/english/a_cn4_145_corr1.pdf $>$.

22 Supra note 14.

23 Frowein, A. J. Recognition. Max Planc Encyclopedia of Public International Law. Heidelberg: Max Planck Institute for Comparative Public Law and International Law, Heidelberg and Oxford University Press. Daugiau apie naujų valstybių, susikūrusių ius cogens normų pažeidimo pagrindu, skaitykite: Dugard, J. Recognition and the United Nations. Cambridge, 1987, p. 123163; Gowlland-Debbas, W. Collective Responses to Illegal Acts in International Law. Dordrecht, 1990; Tancredi, A. Neither Authorized nor Prohibited? Secession and International Law after Kosovo, South Ossetia and Abkhazia. Italian Yearbook of International Law. 2008, 18: 37-62. 
būti palaikytas kaip bet koks tokio statuso pasikeitimo pripažinimas ${ }^{24}$. Pasiryžimas nepripažinti Krymo referendumo bei Krymo ir Sevastopolio neteisèto prijungimo prie Rusijos Federacijos išreikštas $2014 \mathrm{~m}$. kovo 20 d. ${ }^{25}$ ir pakartotas $2014 \mathrm{~m}$. balandžio 14 d. Europos Sąjungos Tarybos (užsienio reikalų) išvadose dèl Ukrainos ${ }^{26}$.

Tarptautinejje teisinèje doktrinoje egzistuoja dvi pagrindinės valstybių pripažinimo teorijos: konstitucinè (teigianti, kad pripažinimas yra valstybingumo kriterijus) ir deklaratyvioji (pagal ją, darinys igyja valstybingumą atitikęs jam keliamus reikalavimus, o pripažinimas tik deklaruoja faktą) ${ }^{27}$. Šiuolaikinèje tarptautinèje teisèje deklaratyvioji pripažinimo teorija dominuoja: Badinterio arbitražo komitetas, nagrinèjęs JSFR iširimo klausimą, konstatavo, kad „valstybės egzistavimas ar išnykimas yra fakto klausimas; kitų valstybių pripažinimo poveikis grynai deklaratyvus" ${ }^{\text {“28; }}$ toks požiūris įtvirtintas ir $1933 \mathrm{~m}$. Montevideo konvencijoje ${ }^{29}$. Pirmiausia reikia pripažinti, kad normalūs tarptautiniai santykiai tarp valstybių galimi tik tuo atveju, kai valstybès pripažįsta viena kitos valstybingumą su visomis iš to išplaukiančiomis teisinemis ir politinèmis pasekmėmis. Kitu atveju būtų labai sudètinga tiek užmegzti tarptautinius santykius, tiek juos palaikyti ir pasitikèti, kad kita valstybė tinkamai vykdys savo ìsipareigojimus. Valstybių pripažinimas igalina pripažịstamąją ir pripažịstančiąją valstybes toliau plètoti tarpusavio santykius ne tik naujų, bet ir anksčiau valstybès pirmtakès prisiimtų ịsipareigojimų ir turètų teisių pagrindu.

Valstybių teisių perèmimo kontekste, ypač kol nèra visuotinio naujos valstybės pripažinimo $^{30}$, tačiau naują darinị pripažįsta dalis tarptautinès teisés subjektų, valstybių teisių perèmimas esti gana ribotas, tačiau ịmanomas. Galimybei perimti teises ịtakos turi tiek individualus, tiek kolektyvinis naujo darinio pripažinimas. Atitinkamai, konkrečios valstybės pripažinimo ịtaka reikšminga priklausomai nuo teisių perèmimo objekto ir naujos valstybès susikūrimo būdo. Priklausomai nuo ịsipareigojimų,

24 UN General Assembly resolution adopted on 27 March 2014 No. 68/262. Territorial integrity of Ukraine.

25 Conclusions on Ukraine, approved by the European Council 20 March 2014.

26 Council conclusions on Ukraine, Foreign Affairs Council meeting Luxembourg, 14 April 2014.

27 Supra note 12, p. 97

28 Conference on Yugoslavia, Arbitration Commission Opinion No. 1, 21 November 1991 [interaktyvus]. Tarptautinis Teisingumo Teismas [žiūrèta 2014-01-20]. <http://www.icj-cij. org/docket/files/141/15048.pdf >, p. 5.

293 straipsnis nurodo, kad valstybe politiškai egzistuoja nepriklausomai nuo jos pripažinimo ir net iki pripažinimo turi teisę ginti savo integralumą ir nepriklausomybę, atlikti kitus veiksmus savo viduje. 6 straipsnyje nurodoma, kad pripažinimas reiškia tik tiek, kad pripažįstančioji valstybe sutinka su pripažistamosios subjektiškumu su visomis teisemis ir pareigomis, kylančiomis iš tarptautinès teisès.

30 Visuotiniu pripažinimu čia laikomas prièmimas j̦ JTO arba reikšmingas valstybių, pripažinusių individualiu pagrindu, skaičius, pastaruoju atveju būtinai ịtraukiant valstybès pirmtakès išreikštą pripažinimą, turintị konstitucinị poveikị. 
kurių atžvilgiu galimas teisių perėmimas, pobūdžio priklauso ir galimybės perimti teises iki valstybès pirmtakè išreikšto ir visuotinio naujos valstybės pripažinimo.

Ir 1978 m., ir 1983 m. Vienos konvencijos dèl teisių perémimo kaip pirminị šaltinị, reglamentuojantị teisių peremimą, nurodo suinteresuotų valstybių susitarimą dèl teisių perėmimo. Tačiau priklausomai nuo teisių perèmimo objektų skiriasi minètos suinteresuotosios valstybès, kitaip tariant, subjektai, kurių susitarimas turi reikšmès valstybių teisių perèmimui. $1978 \mathrm{~m}$. Vienos konvencija dèl teisių perèmimo sutartims pirmiausia nurodo ị valstybės teisių perėmèjos ir kitų konkrečios sutarties šalių susitarimus dèl teisių perèmimo ${ }^{31}$. Vadinasi, teisių perèmimo sutartims atveju svarbiausia, kad kita sutarties šalis ar šalys pripažintų naują tarptautinės teisės subjektą. Šiuo atveju pirmtakès pripažinimas gali netureti jokios ittakos. Maža to, $1978 \mathrm{~m}$. Vienos konvencijos 8 straipsnis nurodo, kad galiojančių tarptautinių sutarčių atžvilgiu ịsipareigojimai kitoms valstybėms nepereina teisių perėmejjai tik dẻl to, kad taip susitaria pirmtakè ir teisių perèmèja. Tai dar kartą patvirtinta, kad sutarčių atžvilgiu svarbiausia kitų sutarties dalyvių valia, atitinkamai - jų pripažinimas. Visai kas kita - teisių perėmimas nuosavybės, skolų, archyvų atžvilgiu. Dẻl šių objektų perėmimo $1983 \mathrm{~m}$. Vienos konvencija pirmiausia leidžia spręsti valstybei pirmtakei ir valstybių teisių perėmëjai arba teisių perėméjoms tarpusavyje, jei pirmtakès nebelieka. Kadangi, skirtingai nuo teisių peremimo sutartims, šiuo atveju teisių peremimo klausimais sprendimus pirmiausia priima pirmtake ir peremejja, o ne kitos valstybès, šioje situacijoje svarbiausias pirmtakès pripažinimas, kitų valstybių pripažinimas nėra toks svarbus.

Pripažįstant, kad individualus vienos valstybès pripažinimas paprastai reikšmingas dvišalių tarptautinių susitarimų perèmimui, taip pat konstatuotina, kad kolektyvinès pripažinimo išraiškos formos ịtaka labiau atsiskleidžia daugiašalių sutarčių, sudarytų tarptautinių organizacijų kontekste. Pavyzdžiui, Kosovas, būdamas pripažintas per šimto valstybių, tačiau neturèdamas pirmtakès pripažinimo, „prisièmé gerbti visus tarptautinius ịsipareigojimus, kylančius iš sutarčių, sudarytų pirmtakių darinių, kurių sudètiné dalis jis buvo, t. y. JSFR, arba buvo jų administruojamas, t. y. UNMIK $^{\text {“32 }}$ ir, kai kurioms jị pripažinusioms valstybẻms pateikęs siūlymus dèl teisių perèmimo įsipareigojimams pagal tam tikras dvišales sutartis, su dalimi jų susitare dèl teisių perèmimo konkrečioms sutartims ${ }^{33}$. Vis dèlto „Kosovo nebuvimas JT ir kitų daugiašalių forumų nariu suponuoja tai, kad nepaisant Kosovo ketinimo gerbti i̇sipareigojimus, kylančius iš JSFR sudarytų daugiašalių sutarčių, $<\ldots>$ jis nelaikomas tokių sutarčiu šalimi, išskyrus tas organizacijas, kurių narys jis yra" ${ }^{\text {"34 }}$.

311978 Vienna Convention on Succession of States in respect of Treaties, United Nations, Treaty Series. Vol. 1946, p. 3.

32 Qerimi, Q.; Krasniqi, S. Theories and Practice of State Succession to Bilateral Treaties: The Recent Experience of Kosovo. German Law Journal. 2013, 14(9): 1639-1659, p. 1645.

33 Ibid., p. 1639-1640.

34 Ibid., p. 1646. 


\section{Valstybių pripažinimo ir teisių perèmimo tarpusavio sąveika, priklausomai nuo valstybių susikūrimo būdo}

Tarptautinejje teisèje nèra prezumpcijos, kad teisių ir pareigų perèmimas tarp valstybių būtinai turi ịvykti. Net ir pati $1978 \mathrm{~m}$. Vienos konvencija (9 straipsnio 1 dalis) nurodo, kad teisių perèmejos vienašalis pareiškimas, kad šioji perimanti teises ir įsipareigojimus, kylančius iš valstybių teisių perèmimo metu galiojančių sutarčių, dar nereiškia, kad teisès ir pareigos būtinai pereis teisių perèmejjai. Valstybių teisių perèmimo apimtis paprastai priklauso ir nuo to, kokiu būdu susiformuoja nauja valstybè. Galima skirti tokius naujos valstybès susiformavimo būdus: susijungimas, teisių tęsimas, išsiskyrimas, atsiskyrimas, cesija. Derètų pabrèžti, kad valstybès suformavimo būdas, atitinkamai - valstybių teisių perėmimo būdas, turi ịtakos valstybių pripažinimui, ir atvirkščiai - valstybių pripažinimas gali daryti ịtaką pasirinktam teisių perèmimo būdui. Maža problemų tuomet, kai valstybės - pirmtakè ir teisių perèmejja ar jų daugetas - sutartiniu pagrindu pasiskirsto teises ir pareigas, kai nekvestionuojamas naujai susiformavusios valstybès valstybingumas ir jos teisès perimti tam tikrą pirmtakès teisių ir pareigų paketą. Didžiausias iššūkis kyla tuomet, kai tokio sutarimo nėra. Šiuo atžvilgiu svarbu pažymėti, kad kitoms valstybėms sprendžiant naujai susiformavusio subjekto pripažinimo ar nepripažinimo klausimą, svarbus ir pirmtakès bei teisių perėmèjos tarpusavio santykis, kuris atitinkamai priklauso nuo naujos valstybės susiformavimo varianto ir pobūdžio.

\subsection{Susijungimas}

Susijungimas aptariamas ir $1978 \mathrm{~m}$. Vienos konvencijos IV dalyje. 31 straipsnio 1 dalis nurodo, kad kalbant apie susijungimą turimas omenyje dviejų ar daugiau valstybių susijungimas, suformuojant vieną valstybę teisių perèmejją ${ }^{35}$. Iš kelių teritorijų susikuria viena nauja valstybè, kuri tampa atsakinga už abiejų buvusių atskirų valstybių ísipareigojimus bei perima abiejų teises. Literatūroje kaip valstybių susijungimo pavyzdys dažnai nagrinejamas Vokietijos Federacinès Respublikos (toliau - VFR) ir Vokietijos Demokratinės Respublikos (toliau - VDR) susivienijimas. Nevertètų VDR ir VFR susivienijimo traktuoti kaip tipinio tokio varianto pavyzdžio, nes VDR buvo prijungta prie VFR. Tai keičia situaciją, nes, kaip mini A. Austas, bent jau tarptautinių sutarčių atžvilgiu, šios, kurių nare buvo VFR, pradèjo galioti visai naujajai teritorijai („judančių sienų principu“), o dèl tų sutarčių, kurios buvo sudarytos išimtinai VDR, vyko derybos su kitomis sutarčių dalyvėmis ir susitarimo būdu išspręsti klausimai dèl tokių sutarčių galiojimo Vokietijos teritorijai ${ }^{36}$. Visa situacija yra kiek skirtinga nuo tos tipinès situacijos, kuri vadinama susijungimu. Valstybių susijungimas, kaip 
jis suprantamas $1978 \mathrm{~m}$. konvencijos kontekste, turi būti vykdomas dviejų ar kelių lygiateisių subjektų. Vokietijos atveju vyko greičiau prisijungimas, o ne susijungimas, atitinkamai, nesusikūrẻ joks naujas subjektas: VFR toliau tęsé savo egzistavimą, o VDR 1990 m. spalio 3 d. tiesiog išnyko ${ }^{37}$.

Valstybių apsisprendimui pripažinti ar nepripažinti tokiu būdu susiformavusi darini ịtakos taip pat gali turèti ir faktas, ar ịvyko valstybių susijungimas, ar prisijungimas. Šiuo atveju svarbi valstybių pirmtakių laisvos valios išraiška ir apsisprendimas bei tai, ar prisijungimo atveju valstybė pirmtakẻ buvo visiškai nepriklausoma. Paprastai valstybių susijungimo atvejais proceso legitimumas preziumuojamas ${ }^{38}$, nes yra laisvanoriškas dviejų ar daugiau valstybių apsisprendimas sukurti naują darinị vietoj anksčiau egzistavusių kelių valstybių. Jei toks apsisprendimas nekelia klausimo dèl jègos ir grasinimo jèga nenaudojimo, valstybių teritorinio vientisumo ir kitu tarptautinès teisés principų pažeidimo, manytina, pripažinimas neturètų trukti ir daryti neigiamos įtakos teisių perėmimui. $\mathrm{O}$ atsižvelgiant $\mathfrak{i}$ tai, kad paprastai tokiu naujos valstybės susiformavimo būdu susikūręs subjektas perima abiejų pirmtakių teises ir pareigas, - neturètų nukentèti ir kitų tarptautinès bendrijos narių interesai. Toks neprobleminio susijungimo pavyzdys galètų būti Jungtinès Arabų Respublikos susikūrimas (Egipto ir Sirijos sąjunga): $1958 \mathrm{~m}$. vasario $21 \mathrm{~d}$. Egipte ir Sirijoje vykusio plebiscito rezultatų pagrindu buvo sukurta Jungtinè Arabų Respublika, o vasario 24 d. Respublikos užsienio reikalų ministras apie šį faktą informavo Jungtinių Tautų Generaliniam Sekretoriui siųstoje notoje ${ }^{39}$. Kovo $1 \mathrm{~d}$. notoje užsienio reikalų ministras taip pat pažymėjo, kad Jungtinè Arabų Respublika yra vienintelè Jungtinių Tautų narè, saistoma ịsipareigojimų pagal Chartiją, ir kad visos tarptautinès sutartys ir susitarimai išliks galiojantys laikantis regioninių apribojimų, nustatytų juos sudarant, bei tarptautinès teisès principų ${ }^{40}$. Pažymètina, kad pripažinimo klausimas ilgai netruko: pavyzdžiui, Jungtinès Valstijos ir Prancūzija pripažino naują valstybę jau vasario 25 d. ${ }^{41}$ Atitinkamai, vieningos Vokietijos sukūrimas, integruojant VDR į VFR neiš-

37 Klabbers, J., et al. State Practice Regarding State Succesion and Issues of Recognition. Kluwer Law International, 1999, p.34

38 Ibid., p. 35.

39 Document A/CN.4/149 and Add.l: The succession of States in relation to membership in the United Nations: memorandum prepared by the Secretariat. Yearbook of the International Law Commission: Documents of the fourteenth session including the report of the Commission to the General Assembly. 1962, II: 101-106.

Ibid.

41 Office of the Historian, Bureau of Public Affairs, United States Department of State [interaktyvus]. Vašingtonas, 2010 [žiūrèta 2013-11-01]. <http://history.state.gov/countries/ syria> ir Jewish Telegraphic Agency archyvas. United States, France Announce Recognition of United Arab Republic [interaktyvus]. Jewish Telegraphic Agency, 1958-02-26 [žiūrèta 201311-07]. <http://www.jta.org/1958/02/26/archive/united-states-france-announce-recognitionof-united-arab-republic\#ixzz2jzkMAX00>. 
kèlè klausimų dèl valstybių ar vyriausybių pripažinimo, ${ }^{42}$ nes vyko abipusio sutarimo pagrindu ir pagal tarptautinę teisę $e^{43}$.

\subsection{Valstybių teisių tęsimas ir išsiskyrimas}

Du naujų valstybių atsiradimo būdai - išsiskyrimas ir teisių tęsimas, turintys ypatingos ịtakos valstybių teisių perèmimo apimčiai, ypač susiję su valstybių pripažinimu. Jiedu aptariami viename poskyryje pirmiausia dèl to, kad, atskirais atvejais pirmtakei yrant, viena jų gali reikšti pretenzijas ị valstybės pirmtakẻs teisių tęsimą, o kitos konkretaus teisinio santykio dalyvès gali tokių aspiracijų nepripažinti, reikalaudamos santykị traktuoti kaip išsiskyrimą.

\subsubsection{Teisių tęsimas}

Literatūroje yra kelios nuomonès dèl teisių tęsimo kaip varianto spręsti teisių ir pareigų perleidimą. Vieni autoriai, pavyzdžiui, V. Vadapalas, teisių tęsimą laiko teisių perèmimo forma, nurodydamas, kad šiuo atveju valstybe teisių perèmėja perima kiek įmanoma daugiau valstybės pirmtakès buvusių teisių ir pareigų, tačiau, kadangi iš esmès ji jau yra atskiras, kitoks darinys nei senoji valstybe pirmtake, jos laikomos skirtingais tarptautinès teisès subjektais, t. y. jos nèra tapačios, situacija vadinama „kontinuitetas be identiškumo “44. Kiti autoriai pasisako, kad valstybių teisių perèmimas ir teisių tęsimas - dvi skirtingos situacijos. „Kai susikuria naujas darinys, jis turi apsispręsti, ar yra visiškai naujas kūrinys valstybės pirmtakės atžvilgiu, ar yra jos tąsa, tik kiek kitokia forma“45. Anot J. Crowfordo, „tarp valstybių tęstinumo ir valstybių teisių perèmimo yra fundamentalus skirtumas: t. y. tarp atvejų, kai „ta pati“ valstybè, galima sakyti, toliau egzistuoja, nepaisant vyriausybès, teritorijos ar populiacijos pokyčių, ir atvejų, kai viena valstybė $\langle\ldots>$ pakeičia kitą tam tikroje teritorijoje “46. Valstybès gali būti laikomos tapačiomis nepaisant kai kurių formaliųjų kriterijų (teritorijos dydžio, valstybés pavadinimo ir pan.) neatitikimo - šią poziciją pagrindžia ir Rusijos Federacijos bei SSRS tapatumo analizè, pateikiama daugelio autorių darbuo$\mathrm{se}^{47}$. D. Žalimas, nurodo, jog „valstybès identitetas - tai valstybès, kaip tarptautinès

42 Klabbers, J., et al. State Practice Regarding State Succesion and Issues of Recognition. Kluwer Law International, 1999, p. 44.

43 Ibid., p. 46.

44 Vadapalas, V. Tarptautine teisé. Vilnius: Eurgimas, 2006, p. 256.

45 Shaw, M. N. International law. Fifth edition. Cambridge: Cambridge University Press, 2003, p. 865 .

46 Crawford, J. The Creation of States in International Law. Second edition. Oxford: Clarendon Press, 2006.

47 Mullerson, R. The Continuity and Succession of States, by Reference to the Former USSR and Yugoslavia. The International and Comparative Law Quarterly. 1993, 42(3): 473-493; Ziemele, I. Is the Distinction between State Continuity and State Succession Reality or Fiction? 
teisès subjekto, tapatumas, kurị atspindi jos teisès ir ịsipareigojimai pagal tarptautinę teisę, iš esmès nepasikeitę po valstybès požymio (požymių) pokyčio, sukẻlusio abejonę dèl tolesnio jos egzistavimo “48. Dera sutikti su autoriais, teigiančiais, kad tais atvejais, kai tokia abejonè atsiranda, svarbi pačios valstybès laikysena ir kitų subjektų pripažinimas ${ }^{49}$. Taigi, sprendimas, ar tapti teisių tęsejja, ar teisių perèmejja, priklauso ne tik nuo paties subjekto apsisprendimo.

Aptariamai teisių tęsimo situacijai labai didelę reikšmę turi tai, ar kitos valstybès pripažista konkretaus subjekto aspiracijas tęsti pirmtakès subjektiškumą. Pirmiausia, aktualus buvusių sudètinių valstybès dalių, po valstybių teisių peremimo tapusių nepriklausomomis valstybèmis, pripažinimas. I̦ šį pripažinimą daugiausia atsižvelgia ir kitos tarptautinès bendrijos narès: tiek individualiai spręsdamos pripažinimo klausimą, tiek kolektyviai nagrinėdamos klausimą dèl pasiskelbusios teisių tęsẻja valstybès tolesnès narystės tarptautinėse organizacijose. Pasakytina, kad tokių aspiracijų pripažinimas gali būti menamas, t. y. laikantis neprieštaravimo pozicijos, pavyzdžiui, neprieštaraujant dèl narystės tarptautinèse organizacijose tęsimo.

Kadangi teisių tęsimas traktuotinas kaip tapatumas, kaip tolesnè to paties subjekto egzistavimo forma, teisių peremimo pagrindu laikytinas atsiskyrimo variantas. T. y. viena teisinio valstybių teisių perèmimo santykio dalyvé - teisių tęsèja - laikoma valstybe pirmtake, nuo kurios atsiskyrè dalis teritorijos, ir ji toliau tęsia savo egzistenciją, išsprendusi perèmimo klausimus, susijusius su atsiskyrusia (-iomis) teisių perèmeja (-omis). Tokiu atveju pirmtakei formaliai nereikia jos, kaip naujo tarptautinès teisès subjekto, pripažinimo, išreikšto kitų valstybių: pripažinimas reikalingas tik naujai susiformavusiems subjektams. Akivaizdus tokios situacijos pavyzdys - Rusijos Federacija po SSRS žlugimo: po SSRS iširimo nebuvo kilęs klausimas dèl Rusijos Federacijos, kaip naujai susikūrusios valstybès pripažinimo, o valstybès, su kuriomis SSRS buvo užmezgusi diplomatinius santykius, toliau juos palaikè su Rusijos Federacija ir po pirmosios iširimo ${ }^{50}$. Rusija savo ruožtu taip pat perèmè visas ambasadas

The Russian Federation, the Federal Republic of Yugoslavia and Germany; Baltic Yearbook of International Law. 2001, Volume 1; Žalimas, D. Ar Rusija (ne)tapati Sovietu Sajungai? [interaktyvus]. Všt Geopolitinių studijų centras [žiūrèta 2013-12-20] <http://www.geopolitika. $1 \mathrm{t} /$ ?artc $=1565>$.

48 Žalimas, D. Lietuvos Respublikos nepriklausomybès atkūrimo $1990 \mathrm{~m}$. kovo 11 d. tarptautiniai teisiniai pagrindai ir pasekmès. Vilnius: Demokratinès politikos institutas, 2005, p. 170.

49 Žr. Žalimas, D. SSRS okupacijos žalos atlyginimo ịstatymas tarptautinès teisès normu kontekste. Jurisprudencija. 2006,10(88): 22-32, p. 25; Mullerson, R. The Continuity and Succession of States, by Reference to the Former USSR and Yugoslavia. The International and Comparative Law Quarterly. 1993, 42(3): 473-493, p. 477; Crawford, J. The Creation of States in International Law. Second edition. Oxford: Clarendon Press, 2006, p. 406.

50 Ziemele, I. Is the Distinction between State Continuity and State Succession Reality or Fiction? The Russian Federation, the Federal Republic of Yugoslavia and Germany; Baltic Yearbook of International Law. 2001, Volume 1, p. 196. 
bei konsulines i̊staigas, ịkurtas kitose valstybėse ${ }^{51}$. Kiek kitaip i Rusijos Federacijos teisių tęsimą reagavo Jungtinès Amerikos Valstijos, ši valstybė pripažino Rusiją bei užmezgè diplomatinius santykius. Tačiau vis dèlto JAV pripažino Rusijos Federacijos teisių tęsimą SSRS atžvilgiứ ${ }^{52}$. Jei laikytume teisių tęsimą kontinuetu be identiškumo, derètų pripažinti, kad įvyksta išsiskyrimas ir kiekviena nauja susiformavusi valstybė turi būti pripažinta ( kad ir kolektyviniu pripažinimu - priimant i JTO, nes narystė tarptautinèse organizacijose paprastai nèra teisių perèmimo objektas). Kadangi tarptautinè praktika ${ }^{53}$ rodo, kad teisių tęsèjai tokių žingsnių atlikti nereikia, manytina, kad teisių tęsèja neabejotinai laikytina valstybe pirmtake, tęsiančia savo suverenitetą, nuo kurios atsiskiria jai priklausiusi teritorijos dalis.

\subsubsection{Išsiskyrimas}

Pripažįstant, kad JSFR atveju ịvyko išsiskyrimas, reikètų jị atskirai aptarti. Pažymėtina, kad didelę reikšmę šio proceso klausimų sprendimui turejo Badinterio arbitražo komitetas (kitaip - Konferencijos Jugoslavijai arbitražo komisija) ${ }^{54}$. Šis komitetas, inter alia, teikè pozicijas dèl JSFR teisių perèmimo pagrindo - ar jis yra iširimas, ar atsiskyrimas (atitinkamai - teisių tęsimas JFR atžvilgiu); nagrinèjo Buvusios Jugoslavijos Respublikos Makedonijos, Slovėnijos, Kroatijos, Bosnijos Hercegovinos prašymus dèl pripažinimo, vertindamas, ar jos atitinka Europos Bendrijų keliamus kriterijus ir t. t.

Komitetas nurode், kad valstybès išsiskyrimas reiškia, jog ji daugiau nebeturi teisinio subjektiškumo, o tai turi rimtas pasekmes tarptautinèje teisèje ir neturètų būti lengvai preziumuojama ${ }^{55}$. Pažymėtina, kad Badinterio komiteto išvados dèl situacijos vertinimo (ar JSFR yra beišyranti, ar ji jau nebeegzistuoja), kito priklausomai nuo valstybių pripažinimo, nors nuomonèse buvo pabrèžiama, kad valstybių pripažinimas - grynai deklaratyvus. Pirmojoje nuomonèje komitetas teigè, kad valstybè buvo beišyranti, o aštuntojoje konstatuota iširimo proceso pabaiga. Pastarąją išvadą komi-

51 Žalimas, D. SSRS okupacijos žalos atlyginimo ịstatymas tarptautinès teisės normų kontekste. Jurisprudencija. 2006, 10(88): 25.

52 Ziemele, I. Is the Distinction between State Continuity and State Succession Reality or Fiction? The Russian Federation, the Federal Republic of Yugoslavia and Germany; Baltic Yearbook of International Law. 2001, Volume 1, p. 197.

53 Ne tik Rusijos Federacijos, bet ir Indijos po Pakistano atsiskyrimo, kurio metu Jungtinių Tautų sekretoriatas konstatvo, kad „iš tarptautinès teisès perspektyvų ši situacija yra tokia, kai dalis egzistuojančios valstybès atsiskiria ir tampa nauja valstybe“ (žr. Mullerson, R., supra note 47), taip pat kaip ir Juodkalnijos atsiskyrimo nuo Serbijos (žr. Žalimas, D., supra note 47) atvejais.

54 Badinterio komitetas $1991 \mathrm{~m}$. rugpjūčio 27 d. sudaryras Europos ekonominès bendrijos Ministrų tarybos teikti rekomendacijas Konferencijai Jugoslavijai teisiniais klausimais.

55 Conference on Yugoslavia, Arbitration Commission Opinion No. 8, 4 July, 1992 [interaktyvus]. Tarptautinis Teisingumo Teismas [žiūrèta 2014-01-20]. <http://www.icj-cij.org/docket/files/ 141/15048.pdf_>. 
tetas grindè tuo, kad valstybès, paskelbusios nepriklausomybę, vertinimo metu jau buvo pripažinusios viena kitą, kai kurios jų - pripažintos Europos Bendrijų, taip pat priimtos i JTO, kurios rezoliucijose JSFR buvo įvardijama kaip buvusi (angl. former SFRY), o JFR aspiracijos tęsti narystę JT nepasiteisino. Pažymètina, kad JT 1992 m. gegužès $30 \mathrm{~d}$. rezoliucijos Nr. 757 preambuleje, inter alia, pažymëjo, kad JFR siekis automatiškai tęsti buvusios JSFR narystę JTO nebuvo bendrai priimtas ${ }^{56}$. Ir vis dèlto, nors „Jungtinès Tautos nepripažino Jugoslavijos kaip buvusios Jugolsavijos teisių tęsejjos, tačiau depozitoriume nuolatos buvo rašomas Jugoslavijos pavadinimas prie sutarčių, kurių šalimi buvo buvusi Jugoslavija" ${ }^{\text {"57 }}$.

Pažymètina, kad, Europos Bendrijos, spręsdamos JFR pripažinimo klausimą, laikèsi kiek kitokios pozicijos nei kitų sąjunginių valstybių pripažinimo metu. Kaip pažymi M. Škrk, JFR nebuvo taikomas kreipimosi dèl pripažinimo mechanizmas, jai pripažinti ES kèlè kelias pagrindines sąlygas - su kitomis atsiskyrusiomis valstybėmis pripažinti viena kitą ir gera valia išspręsti tarpusavio valstybių teisių peremimo klausimą, ko JFR nedarè nuo $1992 \mathrm{~m} .{ }^{58}$ Taigi, dar kartą patvirtinama buvusių sąjunginių valstybių tarpusavio pripažinimo reikšmè tam, kad būtų išspręsti teisių perėmimo klausimai. Pažymètina, kad kol JFR nepripažino, kad įvyko išsiskyrimo, o ne atsiskyrimo situacija, manè, kad pati, kaip teisių tęsèja, ir turi perimti visas JSFR teises ir pareigas. Tik $2001 \mathrm{~m}$. birželio 29 d., po ilgalaikių derybų, buvo priimtas susitarimas dèl teisių perémimo klausimų (Agreement on Succession Issues) ${ }^{59}$.

Aptariant iširimo atvejus, derètų paminèti dar vieną situaciją - Čekijos ir Slovakijos Federacinès Respublikos (ČSFR) iširimą. ČSFR išsiskyrimo atveju, abi - tiek Čekija, tiek Slovakija - pasiskelbè pirmtakès teisių ir pareigų perėmejjomis. Šiuo atveju, nepaisant to, kad Čekijos Respublika teritoriškai didesnè, nebuvo jokių pretenziju būti pirmtakès teisių tęsèja ${ }^{60}$. Išsiskyrimas vyko abiejų valstybių susitarimo pagrindu ir todèl nekilo problemų dèl valstybiu ar vyriausybių pripažinimo ${ }^{61}$. Abi naujosios valstybės turejo iš naujo, kaip naujos nepriklausomos valstybès, tapti tarptautinių organizacijų narèmis.

56 UN Security Council Resolution of UN Security Council Resolution of 30 May 1992 No. S/ RES/757 (1992)

57 Jakulevičienė, L. Tarptautinių sutarčiu teisé. Vilnius: VỊ Registrų centras, 2011, p. 354.

58 Škrk, M. Recognition of States and its (Non)-Implication on State Succession: the Case of Successor States to the Former Yugoslavia. Succession of States. Netherlands: Kluwer Law International, 1999, p. 1-31.

59 Agreement on Succession Issues, done at Vienna on 29 June 2001 [interaktyvus]. United Nations Treaty Collection [žiūrèta 2014-03-06]. <https://treaties.un.org/doc/source/ recenttexts/29-1.pdf>.

60 Aust, A. Modern treaty law and practice. Second edition. Cambridge: Cambridge University Press, 2007, p. 318.

61 Klabbers, J., et al. State Practice Regarding State Succesion and Issues of Recognition. Kluwer Law International, 1999, p. 42. 
Išsiskyrimo metu naujos valstybės pasidalija (žinoma, priklausomai nuo valstybių valios) tarpusavyje pirmtakès įsipareigojimus ir teises. Atitinkamai, naujai susikūrusios valstybès turi būti pripažintos tarptautinės bendrijos. Kadangi išsiskyrimas paprastai turètų būti taikaus pobūdžio sprendimas, nes sprendimas paprastai priimamas visapusiu sutikimu, kitoms valstybėms jo kvestionuoti nėra politinio pagrindo. Dèl šios priežasties pripažinimo klausimus spręsti geriausia paprasčiausiu būdu - kolektyviai - igyvendinat teisę tapti JTO narèmis.

\subsection{Atsiskyrimas}

1978 m. Vienos konvencijos 34 straipsnis aptaria teisinius padarinius, kai valstybès teritorijos dalis ar dalys atsiskiria tam, kad suformuotų vieną ar daugiau valstybių, nepaisant to, ar valstybé pirmtakè toliau egzistuoja, ar ne. Konvencijos 35 straipsnis konkrečiai skirtas aptarti situacijoms, kai valstybė pirmtakẻ toliau egzistuoja. Atsiskyrimas tarptautinès teisès mokslininkų taip pat nagrinejjamas nevienoda apimtimi. Autoriai, nagrinejjantys atsiskyrimo klausimą plačiąja prasme, „itraukia ị savo analizę visus valstybių išsiskyrimo atvejus, kai valstybė pirmtakè tęsia savo egzistavimą sumažèjusių teritorijos ir demografinès padèties forma. Situacijos, kai valstybè pirmtakè nustoja egzistuoti, taip pat apžvelgiamos. <...> Siauresne koncepcijos prasme, atsiskyrimas yra naujo nepriklausomo darinio susikūrimas, daliai teritorijos ir populiacijos atsiribojant nuo egzistuojančios valstybės, be pastarosios sutikimo"62. Siekiant atskirai aptarti valstybių pripažinimo įtaką valstybių teisių perémimui, valstybių atsiskyrimu laikysime situaciją, kai dalis teritorijos atsiskiria nuo valstybės pirmtakès, o pirmoji ir toliau egzistuoja. Situacija, kai valstybės pirmtakès nebelieka, vadinama išsiskyrimu ir aptarta anksčiau. Derètų atkreipti dèmesị, kad M. G. Kohenas, nurodydamas siauresnị atsiskyrimo tyrinéjimo modelị, kaip požymị nurodè egzistuojančios valstybès sutikimo nebuvimą ${ }^{63}$. Pirmiausia, nereikètų susiaurinti atsiskyrimo tik iki situacijų, kai toliau egzistuojanti valstybè pirmtakè nesutinka su atsiskyrimu. Vis dèlto derètų pabrèžti, kad aptariamai temai valstybés pirmtakès sutikimo klausimas yra ypač svarbus.

Pažymėtina, kad atsiskyrimo atveju, kai jis nèra nei taikus, nei turi pirmtakès sutikimą, pripažinimas turi didelès reikšmès. Pirmiausia, atkreiptinas dèmesys, kad tiek paskiros valstybès, tiek tarptautinès organizacijos atsižvelgia $\mathfrak{i}$ atsiskyrimo teisètumą ir, tokio nesant, laikosi nepripažinimo politikos, pavyzdžiui, spręsdamos ginčus dèl teismų sprendimų pripažinimo. Europos Bendrijų Teisingumo Teismui pateikto Anglijos ir Velso apeliacinio teismo (Jungtinè Karalystė) prašymo dèl prejudicinio sprendimo Generalinès advokatès Kokott išvadoje nurodoma, kad „2003 m. Stojimo 
akto Protokolo Nr. 101 straipsnio 1 dalyje numatytas acquis communautaire taikymo atidejjimas tose Kipro Respublikos dalyse, kuriose Kipro Respublikos vyriausybè nevykdo veiksmingos kontrolès, netrukdo kitos valstybès narès teismui, remiantis Reglamentu Nr. 44/2001, pripažinti ir vykdyti Kipro Respublikos teismo sprendimo, susijusio su jo vyriausybès nekontroliuojama teritorija " ${ }^{\text {"64 }}$. Šioje situacijoje akivaizdus nepripažinimo politikos veikimas. T. y. Europos Sąjungos valstybės narès turi pripažinti graikų Kipro dalies teismo sprendimus ir juos vykdyti, nepaisant to, kad sprendimai susiję su teritorija, kuri nèra kontroliuojama Kipro Respublikos, tačiau visuotinai pripažistama jos dalimi. Atitinkamai - nepripažistama nuo 1974 m. trunkanti Kipro šiaurinès dalies okupacija ir jos vietinès valdžios vykdoma nuosavybès teisių savarankiško perleidimo politika. Valstybès, de facto peremusios nuosavybę (pažymètina, kad ne teisę i nuosavybę), veiksmai nepripažįstami teisių perėmimu, nes kyla iš tarptautinès teisès pažeidimo.

Derètų pažymèti, kad ypatingai svarbus vaidmuo pripažinimo kontekste tenka valstybei pirmtakei. Atsiskyrimas esti gerokai paprastesnis ir greitesnis tuomet, kai valstybė pirmtakè pati pripažista naujai susiformavusio darinio valstybingumo siekius. Pavyzdžiui, Pietų Sudanas, $2011 \mathrm{~m}$. sausio mèn. surengęs referendumą, liepos 9 d. paskelbęs nepriklausomybę, Sudano buvo pripažintas tą pačią dieną, kaip ir kai kurių kitų valstybių, o jau liepos 14 d. galèjo džiaugtis naryste Jungtinių Tautų Organizacijoje ir po to ejusiu atskirų valstybių pripažinimu ${ }^{65}$. Vis dèlto nederètų pamiršti ịvykių istorinès trukmès: Pietų Sudano ir Sudano santykiai dèl naujos valstybès sprendèsi ilgą laiką - taikaus sprendimo pradžia laikytini 2005 m., kai baigèsi dešimtmečius trukęs kruvinas pilietinis karas. 2005 m. taikos sutarties tarp Sudano vyriausybès ir Sudano tautos išsivadavimo judejimo / Sudano Tautos išsivadavimo armijos preambuleje pažymima, kad šalys pripažǐsta Pietų Sudano žmonių teisę i apsisprendimą ir kartu siekia pereinamuoju laikotarpiu padaryti vienybę patraukliąa ${ }^{66}, o$

64 Generalinès advokatès Juliane Kokott išvada, pateikta 2008 m. gruodžio 18 d. byloje Meletis Apostolides prieš David Charles Orams ir Linda Elizabeth Orams Nr. C-420/07 (Court of Appeal (England \& Wales) (Civil Division) (Jungtinė Karalystė) pateiktas prašymas priimti prejudicini sprendimą) [interaktyvus]. 2012 [žiūrèta 2013-11-19]. <http://eur-lex.europa.eu/ LexUriServ/LexUriServ.do?uri=CELEX:62007CC0420:LT:NOT>.

65 UN welcomes South Sudan as $193^{\text {rd }}$ Member State [interaktyvus]. UN News Center, 2011 [žiūrèta 2013-11-24]. <http://www.un.org/apps/news/story.asp/http\%3Cspan\%20 class='pullme $\% 3$ EIt $\% 20$ has $\% 20$ become $\% 20$ increasingly $\% 20$ clear $\% 20$ that $\% 20$ disasters $\% 20$ are $\% 20$ setting\%20back\%20 efforts\%20in\%20development $\% 20 \%$ E2\%80\%93\%20they\%20 can $\% 20$ cripple $\% 20$ the $\% 20$ economy, $\% 20$ destroy $\% 20$ infrastructure, $\% 20$ and $\% 20$ plunge $\% 20$ more\%20people\%20into\%20poverty\%3C/span\%3E://www.unisdr.org/www.iaea.org/story.asp ?NewsID $=39034 \& C r=S o u t h+S u d a n \& C r 1=\# . U p J a r 429 t d h>$.

66 The Comprehensive Peace Agreement between the Government of the Republic of the Sudan and the Sudan People's Liberation Movement/Sudan People's Liberation Army [interaktyvus]. 2005 [žiūrèta 2013-11-24]. <http://unmis.unmissions.org/Portals/UNMIS/Documents/ General/cpa-en.pdf>. 
Mačakos protokolo ${ }^{67} 2.5$ punktas nustato, kad pereinamojo laikotarpio šeštųjų metų pabaigoje bus organizuojamas Pietų Sudano žmonių referendumas, kuriame jie nuspręsiantys, ar patvirtinti Sudano vienybę su taikos sutartyje nustatyta valdymo sistema, ar balsuoti už atsiskyrimą ${ }^{68}$. Tam tikri valstybių teisių perémimo sprendimai aiškūs jau dabar - 2012 m. rugsèjo 27 d. Etiopijos sostinejje Adis Abeboje, remiant Afrikos Sąungos aukšto lygio igyvendinimo komisijai (AUHIP), pasirašyti 9 Sudano ir Pietų Sudano susitarimai ${ }^{69}$. Šie susitarimai apėmè bendradarbiavimo, naftos, saugumo, piliečių, pašto paslaugų, prekybos, bankininkystès, sienos, taip pat tam tikrus ekonominius klausimus.

Skirtingai nei Pietų Sudano atveju, kitas atsiskyrimo variantas - Kosovas - nèra pripažintas valstybès pirmtakès - Serbijos. Neturint pirmtakès pripažinimo, valstybės kelias kitų subjektų pripažinimo link ypač sudėtingas: praejjus šešeriems metams nuo nepriklausomybès paskelbimo, jis nèra visuotinai pripažintas. Vis dèlto ši valstybė turi jau kiek didesnị nei pusès JT valstybių narių palaikymą - jis pripažintas jau daugiau nei 100 valstybių $^{70}$, dar $2009 \mathrm{~m}$. prisijungè prie Tarptautinio valiutos fondo, Pasaulio Banko grupès, o po trejų su puse metų tapo visateisiu Europos rekonstrukcijos ir plètros banko nariu ${ }^{71} .2007$ m. kovo 26 d. išsamiame pasiūlyme dèl Kosovo statuso sprendimo ${ }^{72}$ pateikiami ir siūlymai, kurie susiję su valstybių teisių perèmimu. 1.8 pasiūlymo punkte nurodoma, kad Kosovas nesudarys jokių sąjungų su kitomis valstybėmis ar jų teritorijų dalimis. Šiuo atveju patvirtinama, kad pasirinktas atsiskyrimo modelis, o ne prisijungimas ar koks kitoks variantas. Vis dèlto, kol su valstybe pirmtake nebus išspręstas pripažinimo klausimas, visapusio valstybių teisių perèmimo klausimų išsprendimo tikètis neverta. Kita vertus, Kosovas sėkmingai plètoja naujai užmegztus tarptautinius santykius su tomis valstybėmis, kurios ji yra pripaži-

67 Mačakos protokole, sutartame dar $2002 \mathrm{~m}$., kuris vèliau tapo visa apimančio taikos susitarimo (Ibid.) dalimi, buvo nustatyti terminai ir užduotys pasirengimo pereinamajam laikotarpiui (angl. pre-interim period) ir pereinamojo laikotarpio (angl. interim period), kuris turèjęs trukti šešerius metus nuo pasirengimo pereinamajam laikotarpiui pasibaigimo, metu.

68 The Machakos Protocol. Ibid.

69 Nine Agreements between Sudan and South Sudan Sept. 2012 re: Cooperation, Security, Borders, Cross Border Trade, Banking, Post Service Benefits, Citizenship and Status of Nationals, Certain Economic Matters, Oil; plus two Agreements March 2013 re: Implementation Modalities for Security Arrangements \& Adoption of Implementation Matrix incl. Abyei Area (TASA). Sudan Watch [interaktyvus]. 2013-03-16 [žiūrèta 2013-12-01]. <http://sudanwatch. blogspot.com/2013/03/full-text-nine-agreements-between-sudan.html>.

70 Who Recognized Kosova as an Independent State? Kosovo thanks you [interaktyvus] 2014 [žiūrèta 2014-05-04]. <http://www.kosovothanksyou.com/>.

71 Kosovo overview. Pasaulio bankas [interaktyvus]. 2013 [žiūrèta 2013-11-25]. <http://www. worldbank.org/en/country/kosovo/overview $>$.

72 Letter dated 26 March 2007 from the Secretary General addressed tothe President of the Security Council. Addendum: Comprehensive Proposal for the Kosovo Status Settlement Nr. S/2007/168/Add.1. 
nusios: pavyzdžiui, Lietuvos Respublikos Seimas dar 2008 m. gegužès 6 d. nutarimu pripažino Kosovo nepriklausomybę ${ }^{73}$, Vyriausybès $2008 \mathrm{~m}$. liepos $16 \mathrm{~d}$. nutarimu ${ }^{74}$ priimtas sprendimas užmegzti diplomatinius santykius su Kosovo Respublika, o 2012 m. Kosovas akreditavo pirmąji savo ambasadorių Lietuvai ${ }^{75}$. Atitinkamai, Kosovas, net neturedamas pirmtakès pripažinimo, sèkmingai sprendžia tam tikrus valstybių teisių perėmimo sutartims klausimus su Kosovą pripažinusiomis valstybėmis: pavyzdžiui, sudaryti susitarimai dèl teisių perèmimo sutartims su Austrija, Belgija, Čekija, Suomija, Vokietija, Jungtine Karalyste ${ }^{76}$.

Apibendrinant matyti, kad nepripažinimo politikos atveju (Šiaurès Kipro Turkų Respublikos pavyzdys), nepaisant paskelbtos nepiklausomybès, vis tiek pripažistama valstybės pirmtakès jurisdikcija, kartu - ir jos teismų sprendimai okupuotos teritorijos atžvilgiu, nepaisant to, kad pirmtake konkrečios teritorijos nekontroliuoja. Kai atsiskyrę subjektai turi atskirų valstybių pripažinimą, jie gali sudaryti tarptautines sutartis, prisiimti naujus įsipareigojimus, jų teismų sprendimai turi būti pripažinti bent jau tose valstybėse, kurios išreiške pripažinimą. Tas pats pasakytina apie naujai susiformavusios valstybės pasų pripažinimą. Tačiau nesant valstybės pirmtakès pripažinimo, apie valstybių teisių peremimą retrospektyvine prasme kalbèti ypač sudètinga, nors tam tikrų objektų (pavyzdžiui, sutarčių) atžvilgiu įmanoma tiek, kiek teisės perimamos santykiuose su naują subjektą pripažinusiomis valstybemis.

\subsection{Cesija}

M. Cravenas cesiją i̇vardija kaip situaciją, kurioje pagrindinis dèmuo - abipusis sutikimas $^{77}$. Cesijos būdu viena valstybè dalị savo teritorijos perleidžia kitai sutartomis sąlygomis. Toks valstybių teisių peremimo variantas yra ypač retas, nes kiekviena valstybė yra suinteresuota išsaugoti savo valstybės integralumą ir suverenitetą savo teritorijos ribose. Sutartinès cesijos pavyzdžiu laikytinas Elzaso ir Lotaringijos perleidimas Prancūzijai 1919 m. birželio 28 d. Versalio taikos sutartimi, Prancūzija

73 Lietuvos Respublikos Seimo 2008 m. gegužès 6 d. nutarimas Nr. X-1520 „Dèl Kosovo Respublikos pripažinimo“. Valstybès žinios. 2008, Nr. 55-2061.

74 Lietuvos Respublikos Vyriausybès 2008 m. liepos 16 d. nutarimas Nr. 727 „Dèl diplomatinių santykių užmezgimo su Kosovo Respublika“. Valstybès žinios. 2008, Nr. 85-3377.

75 Užsienio reikalu ministras su pirmuoju Kosovo ambasadoriumi Lietuvai aptare galimybes dalintis Europos integracijos patirtimi [interaktyvus]. Vilnius: Užsienio reikalų ministerija, 2012 [žiūrèta 2014-05-26]. <http://www.urm.lt/default/lt/naujienos/uzsienio-reikaluministras-su-pirmuoju-kosovo-ambasadoriumi-lietuvai-aptare-galimybes-dalintiseuroposintegracijos-patirtimi>.

76 Supra note 32, p. 1640.

77 Craven, M. C. R. The Problem of State Succession and the Identity of States under International Law. European Journal of International Law. 1998, 9: 142-162. 
perleido JAV Luizianą 1803 m. balandžio 30 d. Paryžiaus sutartimi. Cesija gali būti tiek atlygintinè, tiek neatlygintinè.

Derètų pažymèti, kad cesijos atveju pripažinimo klausimas apskritai neturi būti sprendžiamas, nes nè viena valstybė nelaikoma nauja, tiesiog vienos teritorija sumažèja, kitos - padidèja. Atitinkamai, teisių perėmimo klausimas šiuo atveju nebepriklauso nuo kitų valstybių pripažinimo, tik nuo susitariančių valstybių - pirmtakès ir perèmejjos - valios (atskirais atvejais sprendimui dèl perèmimo gali turèti ịtakos trečiosios valstybės, kurių interesus liečia teisių ir ịsipareigojimų perleidimas).

Derètų pabrèžti, kad kalbant apie cesiją turimas omenyje sutartinis pagrindas, kai abi valstybės sutinka su sudaromu sandoriu. Nepriimtinas ir negali būti pripažintas faktas, kai viena valstybė, pažeisdama ius cogens normas, prisijungia dali kitos valstybès teritorijos. Tokiu atveju, kaip jau minèta, kitos valstybès turi laikytis ir paprastai didžioji dauguma jų laikosi fakto nepripažinimo politikos (kaip, pavyzdžiui, Krymo aneksijos atveju). Kita vertus, labai svarbu, kad kiekvienu klausimu, susijusiu su valstybės teisių perėmimu, būtų užtikrinta tautų teisẻ ị apsisprendimą ir individualios žmogaus teisès. Atskirais atvejais būtų galima modeliuoti situacijas, kurioms esant sutartiné cesija, kuri iš principo nereikalauja pripažinimo, susidurtų su teritorijos gyventojų, o kartu - su tarptautinès bendrijos pasipriešinimu ir fakto nepripažinimo politika, o faktinė situacija, greičiausiai, vestų naujos nepriklausomos valstybès kūrimo link.

\section{Išvados}

Valstybių teisių perėmimo ir valstybių pripažinimo klausimai glaudžiai susiję. İsipareigojimas išspręsti valstybių teisių perèmimo klausimus gali būti vienu kriterijų, kuriais vadovaudamosi valstybès sprendžia naujo darinio pripažinimo klausimą.

Kai nauju tarptautinès teisès subjektu pasiskelbia darinys, susikūręs tarptautinès teisès pažeidimo pagrindu, paprastai laikomasi nepripažinimo politikos. Šios politikos kontekste de facto perimti objektai (pavyzdžiui, nuosavybė) nelaikomi perèję teisių perèmimo būdu.

Laiko atžvilgiu valstybių pripažinimas paprastai būna anksčiau nei priimami konkretūs sprendimai dèl teisių perèmimo. Vis dèlto nepaisant to, kad naujai susikūręs subjektas neturi visuotinio ir net valstybès pirmtakès pripažinimo, dalinis teisių perèmimas įmanomas. Tokiu atveju perèmimas paprastai įmanomas sutarčių atžvilgiu, nes perimant įsipareigojimus pagal tarptautines sutartis svarbus konkrečios sutarties dalyvių tarpusavio pripažinimas ir valia tęsti ankstesnių ịsipareigojimų vykdymą su nauja valstybe, pirmtakès pripažinimas teisinės reikšmės tokiu atveju beveik neturi. Daugiašalių susitarimų, sudarytų tarptautinių organizacijų kontekste, perėmimo atžvilgiu svarbus konkrečios tarptautinės organizacijos ar jos narių pripažinimas (kartais - būtina narystè šiose organizacijose). Valstybès pirmtakès pri- 
pažinimo klausimas lemiamas, kai sprenžiamas klausimas dẻl teisių peremimo kitų objetų (nuosavybès, skolų, archyvų ir pan.) atžvilgiu.

Valstybių teisių perèmimas ir valstybių teisių tęsimas - dvi skirtingos situacijos, t. y. teisių tęsimas nẻra valstybių teisių perèmimo forma. Teisių tęsimas - situacija, kai pirmtakè tęsia savo egzistenciją tik kiek kitokia forma, gal net pavadinimu. Valstybių teisių peremimas - situacija, kai susikuria naujas darinys, kuris, priklausomai nuo teisių peremimo formos, perima skirtingą teisių ir pareigų dali.

Ryškiausią įtaką pripažinimas turi sprendžiant, ar konkreti valstybė po esmingų (teritorinių, populiacijos ir pan.) pokyčių gali tęsti valstybės pirmtakès teises. Tokių aspiracijų pripažinimas (svarbiausia - kitų konkretaus tarptautinio teisinio santykio dalyvių), kuris gali būti menamas, t. $y$. neprieštaravimo pagrindu, turi konstitucinị poveikị, t. y. konstatuojamas pirmtakès ir teisių tęsėjos tapatumas Jis reiškia, kad teisès ne perimamos, o toliau tęsiama konkrečios valstybės egzistencija, atitinkamai, valstybès teisių tęsèjos atžvilgiu netaikant teisių perèmimą lydinčio proceso (prièmimo i tarptautines organizacijas, dalyvavimo sutartyse (išskyrus atitinkamus atvejus) perémimo ir pan. klausimų atžvilgiu).

Jei pripažistama, kad viena valstybè tęsia pirmtakès valstybingumą kaip valstybė teisių tęsẻja (taigi, kaip valstybė pirmtakè), situacija laikytina atsiskyrimu. Kai teisių tęsimo aspiracijos nepripažįstamos, situacija toliau sprendžiama išsiskyrimo atvejams taikytinų valstybių teisių perėmimo taisyklių pagrindu.

Cesijos ir prisijungimo atvejais paprastai nauja valstybė nesusikuria, todèl klausimų dèl valstybių pripažinimo nekyla. Kadangi šie du teritorijos igijimo pagrindai skiriami kaip savanoriški, grịsti abipusiu valstybių sutikimu, teisių perėmimo klausimai taip pat sprendžiami sutartiniu pagrindu ir reikšmingų neigiamų padarinių neturètų kilti.

Ypatingą reikšmę turi valstybès pirmtakès pripažinimas - jei pirmtakè pripažista naujai susikūrusị subjektą, tiek naujos valstybès egzistavimo, jos tarptautinio pripažinimo, tiek teisių perèmimo klausimai sprendžiami gerokai greičiau (gali būti išspręsti per kelias dienas nuo nepriklausomybès paskelbimo) nei tuo atveju, kai pirmtakè nepripažista teisių perèmèjos (tokie atvejai paprastai būna ịvykus atsiskyrimui).

\section{Literatūra}

Abkhazia profile [interaktyvus]. BBC News, 2013 [žiürèta 2014-04-01]. $<$ http://www.bbc.com/news/worldeurope-18175030>.

Accordance with International Law of the Unilateral Declaration of Independence in Respect of Kosovo,
Advisory Opinion, I.C.J. Reports 2010, p. 403

Agreement on Succession Issues, done at Vienna on 29 June 2001 [interaktyvus]. United Nations Treaty Collection [žiūrèta 2014-03-06]. <https://treaties.un.org/doc/ source/recenttexts/29-1.pdf $>$. 
Akehurst, M.; Malanczuk, P. Šiuolaikinis tarptautines teisés įvadas. Vilnius: Eugrimas, 2000.

Annex, A. No. 5742. Convention on the Contract for the International Carriage of Goods by Road (CMR). United Nations Treaty Series [interaktyvus]. United Nations, 2013 [žiūrèta 201312-03]. <http://treaties.un.org/doc/ Publication/UNTS/Volume\%201980/ volume-1980-A-5742-French.pdf>.

Application of the Convention on the Prevention and Punishment of the Crime of Genocide, Preliminary Objections, Judgment, I. C. J. Reports 1996, p. 595 (žr. septintąji Jugoslavijos preliminarų prieštaravimą, p. 605-606).

Aust, A. Modern treaty law and practice. Cambridge: Cambridge University Press, 2007.

Baltarusijos nuolatinio atstovo Jungtinèse Tautose $1991 \mathrm{~m}$. gruodžio $27 \mathrm{~d}$. laiško Jungtinių Tautų Generaliniam Sekretoriui, JT dok. A/47/60, S/23329, priedas Nr. V.

Cyprus v. Turkey, no. 25781/94, § 59-62, ECHR 2001-IV.

C.N.740.2011.TREATIES-2 (Depositary Notification) [interaktyvus]. Uniter Nations, 2013 [žiūrèta 2013-12-03]. <http://treaties.un.org/doc/Publication/CN/2011/CN.740.2011-Eng. pdf $>$.

Comprehensive Peace Agreement between the Government of the Republic of the Sudan and the Sudan People's Liberation Movement/Sudan People's Liberation Army [interaktyvus]. 2005 [žiūrèta 2013-11-24]. <http://unmis. unmissions.org/Portals/UNMIS/ Documents/General/cpa-en.pdf $>$.

Conclusions on Ukraine, approved by the European Council 20 March 2014.
Council conclusions on Ukraine, Foreign Affairs Council meeting Luxembourg, 14 April 2014.

Conference on Yugoslavia, Arbitration Commission Opinion No. 1, 21 November 1991 [interaktyvus]. Tarptautinis Teisingumo Teismas [žiūrèta 2014-01-20]. <http://www.icj-<cij. org/docket/files/141/15048.pdf>.

Conference on Yugoslavia, Arbitration Commission Opinion No. 2, 11 January 1992 [interaktyvus]. Tarptautinis Teisingumo Teismas [žiūrèta 201401-20]. <http://www.icj-cij.org/docket/files/141/15048.pdf>.

Conference on Yugoslavia, Arbitration Commission Opinion No. 8, 4 July, 1992. [interaktyvus]. Tarptautinis Teisingumo Teismas [žiūrèta 2014-0120]. <http://www.icj-cij.org/docket/ files/141/15048.pdf $>$.

Council conclusions on Ukraine, Foreign Affairs Council meeting. Luxembourg, 14 April 2014.

Craven, M. C. R. The Problem of State Succession and the Identity of States under International Law. European Journal of International Law. 1998, 9.

Crawford, J. The Creation of States in International Law. Second edition. Oxford : Clarendon Press, 2006.

Kosovo overview. Pasaulio bankas [interaktyvus]. 2013 [žiūrèta 2013-1125]. <http://www.worldbank.org/en/ country/kosovo/overview $>$.

Declaration on the Guidelines on the Recognition of New States in Eastern Europe and in the Soviet Union (16 December 1991). European Journal of International Law [interaktyvus]. 1990-2004 [žiūrèta 2013-09-30]. <http://207.57.19.226/journal/Vol4/ No1/art6.html\#TopOfPage $>$. 
Declaration on Yugoslavia. Extraordinary EPC Ministerial Meeting, Brussels, 16 December 1991. European Journal of International Law [interaktyvus]. 1990-2004 [žiūrèta 2014-02-23]. <http://207.57.19.226/journal/Vol4/ No1/art7.html\#TopOfPage $>$.

Document A/CN.4/149 and Add.l: The succession of States in relation to membership in the United Nations: memorandum prepared by the Secretariat. Yearbook of the International Law Commission: Documents of the fourteenth session including the report of the Commission to the General Assembly. 1962, II: 101-106.

Draft Articles on Responsibility of States for Internationally Wrongful Acts, with commentaries [2001]. Report of International Law Commission on the work of its fifty-third session (2001). Yearbook of the International Law Commission.

Dugard, J. Recognition and the United Nations. Cambridge, 1987, p. 123-163.

Dugard, J.; Raič, D. The Role of Recognitionin the Law and Practice of Seccession. Secession: International Law perspectives. New York: Cambridge University Press, 2006, p. 94-137.

Europos Tarybos Parlamentinès Asamblejos rezoliucija Nr. 1113 (1997) dèl situacijos Kipre.

EU Special Representative for the South Caucasus, Semneby P., Perspectives for engagement, dialogue and cooperation to address the consequences of the war between Russia and Georgia: a forward looking approach. Presentation to the Committee on the Honou- ring of Obligations and Commitments by Member States of the Council of Europe of the Parliamentary Assembly of the Council of Europe Hearing on "the consequences of the war between Georgia and Russia", National Assembly, Paris, 17 January 2011 [interaktyvus]. Europos Sąjungos Taryba [žiūrèta 2014-02-20]. <http://www.consilium. europa.eu/media/1252985/speech-pace\%20mc-paris-110117-final.pdf>.

Frowein, A. J. Recognition. Max Planc Encyclopedia of Public International Law. Heidelberg: Max Planck Institute for Comparative Public Law and International Law, Heidelberg and Oxford University Press.

Future work in the field of the codification and progressive development of International Law - Working paper prepared by the Secretariat A/ CN.4/145 [interaktyvus]. International Law Commission [žiūrèta 2013-11-07]. <http://legal.un.org/ilc/ documentation/english/a_cn4_145_ corr1.pdf>.

General Assembly Votes Overwhelmingly to Accord Palestine: ,Non-Member Observer State' Status in United Nations. UN General Assembly [interaktyvus]. New York: UN Department of Public Information News and Media Division [žiūrèta 2014-03-04]. <http://www. un.org/News/Press/docs/2012/ga11317. doc.htm>.

Generalinès advokatès Juliane Kokott išvada, pateikta $2008 \mathrm{~m}$. gruodžio 18 d. byloje Meletis Apostolides prieš David Charles Orams ir Linda Elizabeth Orams Nr. C-420/07 (Court of Appeal (England \& Wales) (Civil Division) (Jungtinè Karalystė) 
pateiktas prašymas priimti prejudicini sprendimą) [interaktyvus]. 2012 [žiūrèta 2013-11-19]. <http://eur-lex.europa. eu/LexUriServ/LexUriServ.do?uri= CELEX:62007CC0420:LT:NOT>.

Gowlland-Debbas, W. Collective Responses to Illegal Acts in International Law, Dordrecht 1990.

Guiding Principles applicable to unilateral declarations of States capable of creating legal obligations, with commentaries thereto. Report of International Law Commission on the work of its Fifty-Eighth Session (2006), General Assembly, Official Records, 61st Session, Supplement No. 10 (A/61/10).

Hillgruber, C. The Admission of New States to the International Community. European Journal of International Law. 1998, 9.

Izraelio užsienio reikalų ministerija [interaktyvus]. 2013 [žiūrèta 2013-1124]. <http://mfa.gov.il/MFA/About TheMinistry/Pages/Israel-s\%20Diplomatic\%20Missions\%20Abroad. aspx\#note>.

Jewish Telegraphic Agency archyvas. United States, France Announce Recognition of United Arab Republic [interaktyvus]. Jewish Telegraphic Agency, 1958-02-26 [žiūrèta 2013-1107]. <http://www.jta.org/1958/02/26/ archive/united-states-france-announce-recognition-of-united-arabrepublic\#ixzz2jzkMAX00>.

Klabbers, J., et al. State Practice Regarding State Succesion and Issues of Recognition. Kluwer Law International, 1999.

Kohen, M. G. Secession: International Law Perspectives. Cambridge: Cambridge University Press, 2006.
Lauterpacht, H. Recognition of States in International Law, 53 YALE L. J. 385, 1944.

Letter dated 8 March 1950 from the Secretary General to the President of the Security Council Transmitting a Memorandum on the Legal Aspects of the Problem of Representation in the United Nations. No. S/1466 [interaktyvus]. History of Macedonia [žiūrèta 2014-03-04]. < http:// www.historyofmacedonia.org/ IndependentMacedonia/UN.html>.

Letter dated 26 March 2007 from the Secretary General addressed to the President of the Security Council. Addendum: Comprehensive Proposal for the Kosovo Status Settlement Nr. S/2007/168/Add.1.

Lietuvos Respublikos Seimo 2008 m. gegužès 6 d. nutarimas Nr. X-1520 „Dèl Kosovo Respublikos pripažinimo“. Valstybès žinios. 2008, Nr. 55-2061.

Lietuvos Respublikos Vyriausybès 2008 m. liepos 16 d. nutarimas Nr. 727 „Dèl diplomatinių santykių užmezgimo su Kosovo Respublika“.Valstybès žinios. 2008, Nr. 85-3377.

Montevideo Convention on the Rights and Duties of States. League of $\mathrm{Na}$ tions Treaty Series. Vol. CLXV, 1936, No. 3802, p. 20-31.

Mullerson, R. The Continuity and Succession of States, by Reference to the Former USSR and Yugoslavia. The International and Comparative Law Quarterly. Vol. 42, No. 3 (Jul., 1993), p. 473-493.

Nine Agreements between Sudan and South Sudan Sept. 2012 re: Cooperation, Security, Borders, Cross Border Trade, Banking, Post Service Benefits, Citizenship and Status of 
Nationals, Certain Economic Matters, Oil; plus two Agreements March 2013 re: Implementation Modalities for Security Arrangements \& Adoption of Implementation Matrix incl. Abyei Area (TASA). Sudan Watch [interaktyvus]. 2013-03-16 [žiūrèta 2013-12-01]. <http://sudanwatch. blogspot.com/2013/03/full-text-nineagreements-between-sudan.html $>$.

Office of the Historian, Bureau of Public Affairs, United States Department of State [interaktyvus]. Vašingtonas, 2010 [žiūrèta 2013-11-01]. <http:// history.state.gov/countries/syria $>$.

Provisional Rules of Procedure of the Security Council, 1983 No. S/96/ Rev.7 [interaktyvus]. Jungtinių Tautų Organizacija [žiūrèta 2014-03-04]. <http://www.un.org/docs/sc/scrules. htm>.

Report of the International Law Commission Fifty-fifth session (5 May-6 June and 7 July-8 August 2003). Official Records of the General Assembly, Fifty-eight session, Supplement No. 10 (A/58/10).

Q\&A: Palestinians' upgraded UN status. BBC [interaktyvus]. 201211-30 [žiūrèta 2013-07-10]. <http:// www.bbc.com/news/world-middleeast-13701636>.

Qerimi, Q.; Krasniqi, S. Theories and Practice of State Succession to Bilateral Treaties: The Recent Experience of Kosovo. German Law Journal. 2013, 14(9).

Separate Opinion of Judge Shahabuddeen. Application of the Convention on the Prevention and Punishment of the Crime of Genocide, Preliminary Objections, Judgment, I. C. J. Reports 1996, p. 595.
Shaw, M. N. International law. Fifth edition. Cambridge: Cambridge University Press, 2003.

Shaw, M. N. State Succession Revisited. Finnish Y.B. Int'l L. 1994, 5 (34).

South Ossetia profile [interaktyvus]. BBC News, 2013 [žiūrèta 2014-04-01]. <http://www.bbc.com/news/worldeurope-18269210>.

State succession to the immovable assets of former Yugoslavia (report). [interaktyvus]. Tarptautinès krizių grupès (International Crisis Group) tinklalapis [žiūrèta 2013-12-20]. <http:// www.crisisgroup.org/ /media/Files/ europe/Bosnia\%206.pdf>.

Škrk, M. Recognition of States and its (Non)-Implication on State Succession: the Case of Successor States to the Former Yugoslavia. Succession of States. Netherlands: Kluwer Law International, 1999, p. 1-31.

Tancredi, A. Neither Authorized nor Prohibited? Secession and International Law after Kosovo, South Ossetia and Abkhazia. Italian Yearbook of International Law. 2008, 18.

UN General Assembly Resolution adopted on 29 November 2012, No. A/ RES/67/19. Status of Palestine in the United Nations.

UN General Assembly resolution adopted on 27 March 2014 No. 68/262. Territorial integrity of Ukraine.

UN Security Council Resolution of 12 November 1965 No. S/RES/216 (1965).

UN Security Council Resolution of 18 November 1983 No. S/RES/541 (1983).

UN Security Council Resolution of 30 May 1992 No. S/RES/757 (1992). 
UN welcomes South Sudan as $193^{\text {rd }}$ Member State [interaktyvus] UN News Center, 2011 [žiūrèta 201311-24]. <http://www.un.org/apps/ news/story.asp/http $\% 3$ Cspan $\% 20$ class='pullme' $\% 3$ EIt $\% 20$ has $\% 20$ become\%20increasingly $\% 20$ clear $\% 20$ that $\% 20$ disasters $\% 20$ are $\% 20$ setting $\% 20$ back $\% 20$ efforts $\% 20$ in $\% 20$ development $\% 20 \%$ E2\% 80\%93\%20 they $\% 20$ can $\% 20$ cripple $\% 20$ the $\% 20$ economy,\%20destroy\%20infrastructure, $\% 20$ and $\% 20$ plunge $\% 20$ more $\% 20$ people $\% 20$ into $\% 20$ poverty $\% 3 \mathrm{C} /$ span\%3E://www.unisdr.org/www.iaea. org/story.asp? NewsID $=39034 \& \mathrm{Cr}=$ So uth+Sudan\&Cr1=\#.UpJar429tdh $>$.

United Nations Treaty Collection [interaktyvus]. United Nations, 2014 [žiūrèta 2014-06-12]. <https:// treaties.un.org/Pages/ViewDetails.aspx? src=TREATY\&mtdsg_ no=XXIII-2\&chapter $=23$ \&lang=en $>$.

Update Report No. 2: Palestine's Application for Admission to the UN [interaktyvus]. Security Council Report, 21 September 2011 [žiūrèta 2014-0304]. <http://www.securitycouncilreport. org/update-report/lookup - c glKWLeMTIsG-b-7743619.php>.

Užsienio reikalu ministras su pirmuoju Kosovo ambasadoriumi Lietuvai aptaré galimybes dalintis Europos integracijos patirtimi [interaktyvus]. Vilnius: Užsienio reikalų ministerija, 2012 [žiūrèta 2014-05-26]. <http://www. urm.lt/default/lt/naujienos/uzsienioreikalu-ministras-su-pirmuoju-kosovo-ambasadoriumi-lietuvai-aptaregalimybes-dalintiseuropos-integracijos-patirtimi>.

Vadapalas, V. Tarptautine teisé. Vilnius: Eurgimas, 2006.
1983 Vienna Convention on Succession of States in respect of State Property, Archives and Debts, Official Records of the United Nations Conference on Succession of States in Respect of State Property, Archives and Debts, vol. II.

1978 Vienna Convention on Succession of States in respect of Treaties, United Nations, Treaty Series, vol. 1946, p. 3.

1969 m. Vienos konvencija dèl tarptautinių sutarčių teisès. Valstybès žinios. 2002, Nr. 13-480.

Villiger, M. E. Commentary on the 1969 Vienna Convention on the Law of Treaties. Boston: Martinus Nijhoff Publishers, 2009, p. 903.

Who Recognized Kosova as an Independent State?Kosovo thanks you. [interaktyvus]. 2014 [žiūrèta 2014-0504]. <http://www.kosovothanksyou. $\mathrm{com} />$.

Ziemele, I. Is the Distinction between State Continuity and State Succession Reality or Fiction? The Russian Federation, the Federal Republic of Yugoslavia and Germany; Baltic Yearbook of International Law. 2001, Volume 1.

Žalimas, D. Ar Rusija (ne)tapati Sovietu Sajungai? [interaktyvus]. Všt Geopolitinių studijų centras [žiūrèta 201312-20]. <http://www.geopolitika. $\mathrm{lt} /$ ? artc $=1565>$.

Žalimas, D. Lietuvos Respublikos nepriklausomybès atkūrimo $1990 \mathrm{~m}$. kovo 11 d. tarptautiniai teisiniai pagrindai ir pasekmès. Vilnius: Demokratinès politikos institutas, 2005.

Žalimas, D. SSRS okupacijos žalos atlyginimo istatymas ir Rusijos Federacijos atsakomybès tarptautiniai teisiniai 
pagrindai [interaktyvus]. Vilniaus universiteto leidykla $<\mathrm{http}: / /$ www.leidykla.eu/fileadmin/Politologija/44/Dainius_Zalimas.pdf>.
Žalimas, D. SSRS okupacijos žalos atlyginimo įstatymas tarptautinès teisès normų kontekste. Jurisprudencija. 2006, 10(88).

Anotacija. Straipsnyje nagrinèjamas valstybiu pripažinimo ir valstybiu teisiu perèmimo institutu sąveikos klausimas. Aptariami pamatiniai valstybiu pripažinimo klausimai, kurie turi įtakos galimam institutu tarpusavio ryšiui nagrinèti: valstybiu pripažinimas kaip valstybès vienašalis sprendimas, jo politine ir teisiné prigimtis ir sprendimu dèl pripažinimo prièmimas tarptautinèse organizacijose. Analizuojama valstybiu pripažinimo reikšmé valstybiu teisiu perémimo procesams, ju turiniui ir spartai priklausomai nuo valstybiu teisiu perèmimo objektu ir büdo, kuriuo susiformavo nauja valstybe. Aptariami teisių perèmimo klausimai, kai naujai susikūręs subjektas pripažistamas tik dalies tarptautines bendrijos ir neturi pirmtakes pripažinimo. Atskiriamos valstybiu teisiu peremimo ir valstybiu teisiu tęsimo kategorijos ir tokio atskyrimo reikšme bei abipusè sąveika su valstybiu pripažinimo klausimu.

Reikšminiai žodžiai: valstybiu teisiu perèmimas, valstybiu pripažinimas, valstybe teisiu perèmèja, valstybè teisiu tęsèja, valstybè pirmtaké.

\title{
INTERACTION BETWEEN RECOGNITION AND SUCCESSION OF STATES
}

\author{
Birutė Kunigèlytè-Žiūkienè
}

Mykolas Romeris University, Lithuania

Summary. The first question arising once a new international law subject appears (or declares to be appeared) in international community is the question of recognition, and the question of succession of states is in some instances dependent on the former and comes afterwards. It is obvious that these two institutes of international law are closely interrelated, and in some cases the undertaking to solve the questions of succession has been considered as one of the recognition prerequisites.

Recognition plays a major role when solving questions of succession, especially depending on the type of creation of a new state. Once the creation of a new state is peaceful and agreed, in most cases the recognition follows shortly, and the questions of succession are being agreed upon afterwards without problems. If the creation of the state is not agreed with a predecessor state (usually in cases of secession), it might take time to solve the questions of recognition as well as those of succession, therefore, the recognition of a predecessor state plays a major role. In cases of continuity of the 
predecessor state (which is not a form of succession, but rather the further existence of the predecessor state), recognition - initially by other subjects of a certain legal relation - successor states - has a constitutive meaning.

It must be noted that if an entity declares itself to be independent or incorporated into another country on the basis of a breach of international law, other subjects of international law usually use the non-recognition policy. In this case, no state succession should take place.

Keywords: recognition of state, succession of states, successor state, predecessor state.

Birutė Kunigèlytė-Žiūkienė, Mykolo Romerio universiteto Tarptautinès ir Europos Sąjungos teisès instituto doktorantė. Mokslinių interesų kryptys: valstybių teisių peremimas, tarptautinè teisinè atsakomybè, tarptautinių sutarčių teisè, diplomatinè ir konsulinè teisè.

Birutė Kunigèlytė-Žiūkienė, Mykolas Romeris University, Institute of International and European Union Law, doctoral student. Research interests: succession of states, international responsibility, international law of treaties, diplomatic and consular law. 